Яценко І. В., доктор ветеринарних наук, Кириченко В. М., лікар ветеринарної медицин

Харківська державна зооветеринарна академія

\title{
БАКТЕРІАЛЬНІ ПОКАЗНИКИ ПРОДУКТІВ ЗАБОЮ КУРЧАТ-БРОЙЛЕРІВ У РАЗІ ЗБАГАЧЕННЯ РАЦІОНУ НАНОМІКРОЕЛЕМЕНТНОЮ КОРМОВОЮ ДОБАВКОЮ «МІКРОСТИМУЛІН» В АСПЕКТІ ВЕТЕРИНАРНО-САНІТАРНОЇ ЕКСПЕРТИЗИ
}

\section{Рецензент - доктор ветеринарних наук, професор І. О. Жукова}

Проаналізовано бактеріальну контамінацію умовнопатогенними та патогенними мікроорганізмами продуктів забою курчат-бройлерів (білі $i$ червоні м'язи, серие, печінка, м'язова частина шлунку) в разі збагачення раціону наномікроелементною кормовою добавкою (НМКД) «Мікростимулін» протягом чотирьох діб зберігання за температури 0-4 ${ }^{\circ} \mathrm{C}$. Встановлено, щзо найменший рівень МАФАнМ, БГКП, бактерій роду Proteus реєструвався в 3-й дослідній групі, курчатам-бройлерам якої задавали з водою $20 \mathrm{~cm}^{3} / \mathrm{\partial м}^{3}$ НМКД «Мікростимулін» у всіх досліджуваних продукmax забою. Найбільший рівень МАФАнМ, БГКП, бактерій роду Proteus реєструвався в контрольній групі, курчатам-бройлерам якої не задавали НМКД «Мікростимулін» з водою. Доведено залежність між дозою НМКД «Мікростимулін» $і$ кількістю мікроорганізмів у продуктах забою птиці.

Ключові слова: продукти забою птиці, бактеріальна контаміначія, курчата-бройлери, мікроорганізми, наномікроелементна кормова добавка «Мікростимулін».

Постановка проблеми. Птахівництво, як галузь тваринництва, $є$ прогресивною і постійно удосконалюється. Від інших галузей тваринництва вона відрізняється високим коефіцієнтом відтворення поголів'я та скоростиглістю, що робить ії основним джерелом забезпечення населення білками тваринного походження. Виробництво м'яса птиці становить $68,2 \%[2,6]$. Проте в умовах постійного зростання вартості комбікормів, важливим завданням $є$ отримання більших приростів живої маси на кілограм використаних кормів. Для цього у птахівництві використовують кормові добавки. Проте використання різноманітних кормових добавок можуть негативно впливати на якість та безпечність продуктів забою, тому виникає потреба у проведенні їх ветеринарно-санітарної експертизи. Одним із показників безпечності продуктів забою $є$ їх бактеріальна контамінація.

Аналіз останніх досліджень і публікацій, у яких започатковано розв'язання проблеми. Наномікроелементна кормова добавка (НМКД)
«Мікростимулін» призначена для корекції і резистентності організму [5]. Фотіна Г. А. [15, 16] дослідила ефективність НМКД «Мікростимулін» у комплексній профілактиці бактеріальних інфекцій птиці. Автор довела, що вона характеризується вираженими профілактичними властивостями за експериментального мікоплазмозу та ешерихіозу птиці. Крім того, вона позитивно впливає на приріст маси тіла бройлерів за період вирощування. Однак бактеріальні показники продуктів забою курчат-бройлерів під час їх зберігання за температури $0-4{ }^{\circ} \mathrm{C}$ у разі застосування цієї кормової добавки не досліджувались, тому досліджуване питання $є$ актуальним.

Мета дослідження - довести, що бактеріальна контамінація продуктів забою курчат-бройлерів (білі і червоні м'язи, серце, печінка, м'язова частина шлунку) в разі збагачення раціону наномікроелементною кормовою добавкою (НМКД) «Мікростимулін» протягом чотирьох діб зберігання за температури $0-4{ }^{\circ} \mathrm{C}$ не перевищує максимально допустимих рівнів і вони можуть випускатися для реалізації без обмежень.

\section{Завдання дослідження:}

1) встановити рівень бактеріальної контамінації продуктів забою курчат-бройлерів у випадку збагачення раціону наномікроелементною кормовою добавкою «Мікростимулін»;

2) порівняти отримані дані дослідних груп птиці з контрольною групою;

3) визначити групи з мінімальним та максимальним бактеріальним забрудненням.

Матеріал і методи дослідження. Досліджували м'ясо курчат-бройлерів, кросу «Кобб-500» забійного віку (42 доби). Годували птицю протягом дослідного періоду сухими повнораціонними комбікормами фірми ТОВ «Фідлайф» (основний раціон) у відповідності до норм ВНДТІП. 3 1-ї до 18-ї доби життя курчат задавали стартовий, 3 19-ї до 37-ї - відгодівельний і з 38-ї до 42-ї - фінішний комбікорми.

В годівлі курчат використовували наномікроелементну кормову добавку (НМКД) «Мікро- 


\section{ВЕТЕРИНАРНА МЕДИЦИНА}

стимулін» [3], у склад якої входять наномікроелементи: мідь, кобальт, магній, цинк, срібло і германій, отримані методом Каплуненка-Косінова [4]. Для цього було сформовано 3 дослідних i одну контрольну групи по 5 голів у кожній групі. Курчата першої дослідної групи отримували основний раціон (ОР), а також їм випоювали НМКД «Мікростимулін» у дозі 1 мл/л води 5 діб поспіль 3 інтервалом у 5 діб; курчатам другої дослідної групи - ОР + 10 мл/л води, третьої групи - ОР + 20 мл/л води «Мікростимуліну» 5 діб поспіль з інтервалом у 5 діб протягом 42 діб 3 5-ї доби після вилуплення до 42-ї доби життя. Курчата контрольної групи отримували лише основний раціон.

Для мікробіологічних досліджень відбирали проби грудних м’язів (білі), стегнової групи (червоні м’язи), проби печінки, серця та м'язової частини шлунку від тушок курчат-бройлерів, згідно 3 ГОСТ 7702.2.0-95 - [1997-01-01] [8]. Досліджувані проби зберігали в холодильній камері за температури 0-4 ${ }^{\circ} \mathrm{C}$. Дослідження проводили через 24 години зберігання 4 дні поспіль.

Рівень бактеріальної контамінації продуктів забою птиці умовно-патогенною та патогенною мікрофлорою визначали за кількістю мезофільноаеробних і факультативно-анаеробних мікроорганізмів (МАФАнМ) за ГОСТ 7702.2.2.-95 [9], бактерій групи кишкової палички (БГКП) - за ГОСТ 7702.2.2.-95 [10], бактерій роду Proteus - за ГОСТ 7702.2.7-95 [11], Salmonella - за ГОСТ 7702.2.393 [12], Stafhylococcus aureus - за ГОСТ 7702.2.495 [13], L. monocytogenes - за ISO 11290-2 : 2003, IDT: ДСТУ ISO 11290-2 : 2003 [7].

Отримані дані обробляли за допомогою методів варіаційної статистики за Стьюдентом.

Результати досліджень. Провівши бактеріологічні дослідження білих (грудних) м'язів курчат-бройлерів усіх дослідних і контрольної груп у разі збагачення раціону НМКД «Мікростимулін» протягом 4-х діб встановлено, що показники МАФАнМ, БГКП та бактерії роду Proteus не перевищують максимально допустимих рівнів [14]. Бактерій роду S. aureus, L. monocytogenes i Salmonella не було виявлено в пробах за увесь період дослідження (табл. 1).

Порівнюючи середні показники дослідних груп 3 контрольною, встановлено, що рівень умовно-патогенної мікрофлори (МАФАнМ, БГКП та бактерії роду Proteus) достовірно нижче $(\mathrm{p} \leq 0,001)$ в усіх дослідних групах на 1-, 2-, 3- та 4-у добу дослідження. Найбільші середні значення кількості виявлених мікроорганізмів реєструвалися в контрольній групі, найменші - у 3-й дослідній групі протягом усього періоду дослід- ження.

У пробах червоних (стегнових) м'язів курчатбройлерів виявили МАФАнМ, БГКП та бактерії роду Proteus (табл. 2). Рівень їх бактеріальної контамінації, як і у білих м'язах, не перевищував максимально допустимих рівнів у всіх дослідних і контрольній групах [14].

Середні показники мікроорганізмів у червоних м'язах дослідних груп, порівнюючи 3 контрольними, достовірно $(\mathrm{p} \leq 0,001)$ нижчі за весь період дослідження. Найбільші середні значення КУО виявлених бактерій містяться в пробах контрольної груп, проте найменші - у 3-й дослідній групі.

Дослідження загальної бактеріальної контамінації серця, печінки та м'язової частини шлунку через 24 годин після забою, показало, що найбільші значення умовно-патогенних мікроорганізмів (МАФАнМ, БГКП і бактерії роду Proteus) були в контрольній групі, а найменші - в пробах 3-ї дослідної груп (табл. 3).

Середній показник КУО МАФАнМ серця всіх дослідних груп достовірно менший у порівнянні 3 контрольним. Найбільше значення КУО МАФАнМ серця курчат-бройлерів реєстрували у пробах контрольної групи - $(8,51 \pm 0,20) \times 10^{3}$ КУО, а найменше - у пробах 3-ї дослідної групи $(7,16 \pm 0,13) \times 10^{3}$ КУО.

Середній показник БГКП у серці достовірно нижчий у 2-й $\left((4,56 \pm 0,13) \times 10^{2}\right.$ КУО) та 3-й $\left((4,33 \pm 0,12) \times 10^{2}\right.$ КУО) дослідних груп проти контролю $(5,21 \pm 0,12) \times 10^{2}$ КУО). Найбільше значення реєструється у пробах контрольної групи, а найменше - у пробах 3-ї дослідної групи.

Найбільший середній показник бактерій роду Proteus виявили в серці курчат-бройлерів контрольної групи $\left((1,02 \pm 0,07) \times 10^{2}\right.$ КУО), а найменший - у серці курчат-бройлерів 3-ї дослідної групи $\left((0,80 \pm 0,03) \times 10^{2}\right.$ КУО). Лише у 3-й дослідній групі середній показник КУО бактерій роду Proteus достовірно $(\mathrm{p} \leq 0,05)$ нижчий за контроль.

Середній показник МАФАнМ проб печінки курчат-бройлерів усіх дослідних груп достовірно менший у порівнянні $з$ контрольними пробами. Так, найбільший рівень бактеріальної контамінації печінки курчат реєструється в контрольній групі $(8,41 \pm 0,11) \times 10^{3}$ КУО, а найменше - в 3-й дослідній групі $(7,01 \pm 0,05) \times 10^{3}$ КУО.

Середній показник БГКП у печінці всіх дослідних груп достовірно менший у порівнянні 3 контрольними пробами. Найбільше значення у контрольній групі - $(6,28 \pm 0,11) \times 10^{2} \mathrm{KУО,} \mathrm{а} \mathrm{най-}$ менше у 3-й дослідній групі $(4,90 \pm 0,13) \times 10^{2}$ KYO. 
BETЕРИНАРНА МЕДИЦИНА

\section{1. Бактеріологічні показники білих м'язів курчат-бройлерів контрольної та дослідних груп} $(n=5, M \pm m)$

\begin{tabular}{|c|c|c|c|c|c|}
\hline \multirow[b]{2}{*}{ Показники } & \multirow{2}{*}{$\begin{array}{c}\text { Доба } \\
\text { зберігання } \\
\left(\mathrm{t}^{\circ} 0-4{ }^{\circ} \mathrm{C}\right)\end{array}$} & \multicolumn{4}{|c|}{ Групи/дози НМКД } \\
\hline & & $\begin{array}{c}1 \\
\left(1 \mathrm{мл} / \text { дм }^{3}\right)\end{array}$ & $\begin{array}{c}2 \\
\left(10 \mathrm{Mл} / \text { дм }^{3}\right)\end{array}$ & $\begin{array}{c}3 \\
\left(20 \mathrm{Mл} / \text { дм }^{3}\right)\end{array}$ & Контрольна \\
\hline \multirow{4}{*}{ 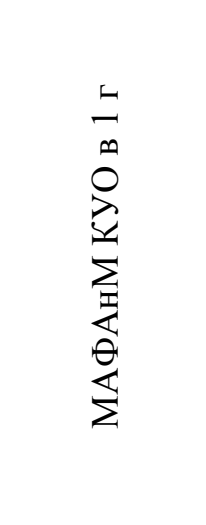 } & 1 & $\begin{array}{c}(1,47 \pm 0,005) \times 10^{3} \\
* * *\end{array}$ & $\begin{array}{c}(1,42 \pm 0,005) \times 10^{3} \\
* * *\end{array}$ & $\begin{array}{c}(1,38 \pm 0,007) \times 10^{3} \\
* * *\end{array}$ & $(1,55 \pm 0,009) \times 10^{3}$ \\
\hline & 2 & $\begin{array}{c}(1,49 \pm 0,007) \times 10^{3} \\
* * *\end{array}$ & $\begin{array}{c}(1,45 \pm 0,004) \times 10^{3} \\
* * *\end{array}$ & $\begin{array}{c}(1,41 \pm 0,006) \times 10^{3} \\
* * *\end{array}$ & $(1,56 \pm 0,007) \times 10^{3}$ \\
\hline & 3 & $\begin{array}{c}(1,51 \pm 0,005) \times 10^{3} \\
* * *\end{array}$ & $\begin{array}{c}(1,47 \pm 0,004) \times 10^{3} \\
* * *\end{array}$ & $\begin{array}{c}(1,42 \pm 0,005) \times 10^{3} \\
* * *\end{array}$ & $(1,60 \pm 0,009) \times 10^{3}$ \\
\hline & 4 & $\begin{array}{c}(1,53 \pm 0,004) \times 10^{3} \\
* * *\end{array}$ & $\begin{array}{c}(1,48 \pm 0,004) \times 10^{3} \\
* * *\end{array}$ & $\begin{array}{c}(1,44 \pm 0,004) \times 10^{3} \\
* * *\end{array}$ & $(1,62 \pm 0,007) \times 10^{3}$ \\
\hline \multirow{4}{*}{$\begin{array}{l}\stackrel{5}{\infty} \\
\stackrel{5}{5}\end{array}$} & 1 & $\begin{array}{c}(1,16 \pm 0,006) \times 10^{2} \\
* * *\end{array}$ & $\begin{array}{c}(1,12 \pm 0,005) \times 10^{2} \\
* * *\end{array}$ & $\begin{array}{c}(1,09 \pm 0,006) \times 10^{2} \\
* * *\end{array}$ & $(1,21 \pm 0,005) \times 10^{2}$ \\
\hline & 2 & $\begin{array}{c}(1,17 \pm 0,004) \times 10^{2} \\
* * *\end{array}$ & $\begin{array}{c}(1,13 \pm 0,006) \times 10^{2} \\
* * *\end{array}$ & $\begin{array}{c}(1,10 \pm 0,007) \times 10^{2} \\
* * *\end{array}$ & $(1,23 \pm 0,007) \times 10^{2}$ \\
\hline & 3 & $\begin{array}{c}(1,19 \pm 0,004) \times 10^{2} \\
* * *\end{array}$ & $\begin{array}{c}(1,14 \pm 0,006) \times 10^{2} \\
* * *\end{array}$ & $\begin{array}{c}(1,12 \pm 0,007) \times 10^{2} \\
* * *\end{array}$ & $(1,25 \pm 0,006) \times 10^{2}$ \\
\hline & 4 & $\begin{array}{c}(1,21 \pm 0,004) \times 10^{2} \\
* * *\end{array}$ & $\begin{array}{c}(1,16 \pm 0,007) \times 10^{2} \\
* * *\end{array}$ & $\begin{array}{c}(1,13 \pm 0,007) \times 10^{2} \\
* * *\end{array}$ & $(1,26 \pm 0,005) \times 10^{2}$ \\
\hline \multirow{4}{*}{\begin{tabular}{ll}
5 & 0 \\
0 & $n$ \\
0 & \multirow{2}{n}{} \\
2 & $\infty$
\end{tabular}} & 1 & $\begin{array}{c}(0,37 \pm 0,005) \times 10^{2} \\
* * *\end{array}$ & $\begin{array}{c}(0,33 \pm 0,004) \times 10^{2} \\
* * *\end{array}$ & $\begin{array}{c}(0,31 \pm 0,004) \times 10^{2} \\
* * *\end{array}$ & $(0,43 \pm 0,007) \times 10^{2}$ \\
\hline & 2 & $\begin{array}{c}(0,39 \pm 0,003) \times 10^{2} \\
* * *\end{array}$ & $\begin{array}{c}(0,35 \pm 0,002) \times 10^{2} \\
* * *\end{array}$ & $\begin{array}{c}(0,32 \pm 0,005) \times 10^{2} \\
* * *\end{array}$ & $(0,44 \pm 0,006) \times 10^{2}$ \\
\hline & 3 & $\begin{array}{c}(0,41 \pm 0,005) \times 10^{2} \\
* * *\end{array}$ & $\begin{array}{c}(0,36 \pm 0,003) \times 10^{2} \\
* * *\end{array}$ & $\begin{array}{c}(0,34 \pm 0,004) \times 10^{2} \\
* * *\end{array}$ & $(0,47 \pm 0,007) \times 10^{2}$ \\
\hline & 4 & $\begin{array}{c}(0,42 \pm 0,007) \times 10^{2} \\
* * *\end{array}$ & $\begin{array}{c}(0,38 \pm 0,004) \times 10^{2} \\
* * *\end{array}$ & $\begin{array}{c}(0,35 \pm 0,003) \times 10^{2} \\
* * *\end{array}$ & $(0,50 \pm 0,007) \times 10^{2}$ \\
\hline $\begin{array}{l}\text { S. aureus, } \\
\text { в } 25 \text { г }\end{array}$ & $1-4$ & \multicolumn{4}{|c|}{ Не виявлено } \\
\hline $\begin{array}{l}\text { L. mono- } \\
\text { cytogenes, } \\
\text { в } 25 \text { г }\end{array}$ & $1-4$ & \multicolumn{4}{|c|}{ Не виявлено } \\
\hline $\begin{array}{l}\text { Salmonella, } \\
\text { в } 25 \text { г }\end{array}$ & $1-4$ & \multicolumn{4}{|c|}{ Не виявлено } \\
\hline
\end{tabular}


ВЕТЕРИНАРНА МЕДИЦИНА

2. Бактеріологічні показники червоних м'язів курчат-бройлерів контрольної та дослідних груп $(n=5, M \pm m)$

\begin{tabular}{|c|c|c|c|c|c|}
\hline \multirow[b]{2}{*}{ Показники } & \multirow{2}{*}{$\begin{array}{c}\text { Доба } \\
\text { зберігання } \\
\left(\mathrm{t}^{\circ} 0-4^{\circ} \mathrm{C}\right)\end{array}$} & \multicolumn{4}{|c|}{ Групи/дози НМКД } \\
\hline & & $\begin{array}{c}1 \\
\left(1 \mathrm{мл} / 2 \mathrm{M}^{3}\right)\end{array}$ & $\begin{array}{c}2 \\
\left(10 \mathrm{Mл} / \mathrm{дм}^{3}\right)\end{array}$ & $\begin{array}{c}3 \\
\left(20 \mathrm{MI} / \mathrm{дM}^{3}\right) \\
\end{array}$ & Контрольна \\
\hline \multirow{4}{*}{ 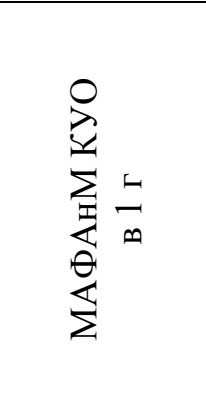 } & 1 & $\begin{array}{c}(1,54 \pm 0,004) \times 10^{3} \\
* * *\end{array}$ & $\begin{array}{c}(1,48 \pm 0,004) \times 10^{3} \\
* * *\end{array}$ & $\begin{array}{c}(1,43 \pm 0,005) \times 10^{3} \\
* * *\end{array}$ & $(1,60 \pm 0,007) \times 10^{3}$ \\
\hline & 2 & $\begin{array}{c}(1,56 \pm 0,004) \times 10^{3} \\
* * *\end{array}$ & $\begin{array}{c}(1,49 \pm 0,005) \times 10^{3} \\
* * *\end{array}$ & $\begin{array}{c}(1,45 \pm 0,005) \times 10^{3} \\
* * *\end{array}$ & $(1,64 \pm 0,006) \times 10^{3}$ \\
\hline & 3 & $\begin{array}{c}(1,58 \pm 0,004) \times 10^{3} \\
* * *\end{array}$ & $\begin{array}{c}(1,51 \pm 0,007) \times 10^{3} \\
* * *\end{array}$ & $\begin{array}{c}(1,47 \pm 0,004) \times 10^{3} \\
* * *\end{array}$ & $(1,67 \pm 0,007) \times 10^{3}$ \\
\hline & 4 & $\begin{array}{c}(1,61 \pm 0,006) \times 10^{3} \\
* * *\end{array}$ & $\begin{array}{c}(1,53 \pm 0,006) \times 10^{3} \\
* * *\end{array}$ & $\begin{array}{c}(1,49 \pm 0,005) \times 10^{3} \\
* * *\end{array}$ & $(1,71 \pm 0,005) \times 10^{3}$ \\
\hline \multirow{4}{*}{ 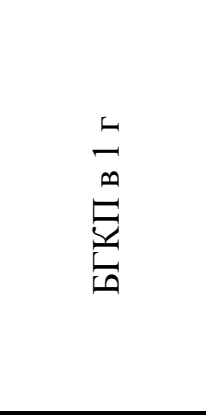 } & 1 & $\begin{array}{c}(1,47 \pm 0,004) \times 10^{2} \\
* * *\end{array}$ & $\begin{array}{c}(1,43 \pm 0,004) \times 10^{2} \\
* * *\end{array}$ & $\begin{array}{c}(1,39 \pm 0,004) \times 10^{2} \\
* * *\end{array}$ & $(1,52 \pm 0,007) \times 10^{2}$ \\
\hline & 2 & $\begin{array}{c}(1,49 \pm 0,004) \times 10^{2} \\
* * *\end{array}$ & $\begin{array}{c}(1,45 \pm 0,006) \times 10^{2} \\
* * *\end{array}$ & $\begin{array}{c}(1,41 \pm 0,005) \times 10^{2} \\
* * *\end{array}$ & $(1,56 \pm 0,007) \times 10^{2}$ \\
\hline & 3 & $\begin{array}{c}(1,51 \pm 0,005) \times 10^{2} \\
* * *\end{array}$ & $\begin{array}{c}(1,47 \pm 0,005) \times 10^{2} \\
* * *\end{array}$ & $\begin{array}{c}(1,42 \pm 0,007) \times 10^{2} \\
* * *\end{array}$ & $(1,58 \pm 0,007) \times 10^{2}$ \\
\hline & 4 & $\begin{array}{c}(1,53 \pm 0,004) \times 10^{2} \\
* * *\end{array}$ & $\begin{array}{c}(1,48 \pm 0,004) \times 10^{2} \\
* * *\end{array}$ & $\begin{array}{c}(1,44 \pm 0,006) \times 10^{2} \\
* * *\end{array}$ & $(1,61 \pm 0,005) \times 10^{2}$ \\
\hline \multirow{4}{*}{ 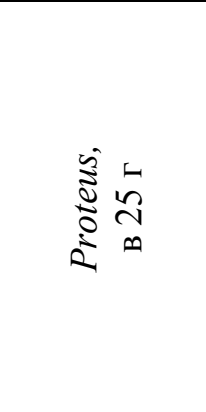 } & 1 & $\begin{array}{c}(0,57 \pm 0,004) \times 10^{2} \\
* * *\end{array}$ & $\begin{array}{c}(0,52 \pm 0,004) \times 10^{2} \\
* * *\end{array}$ & $\begin{array}{c}(0,48 \pm 0,005) \times 10^{2} \\
* * *\end{array}$ & $(0,63 \pm 0,005) \times 10^{2}$ \\
\hline & 2 & $\begin{array}{c}(0,59 \pm 0,005) \times 10^{2} \\
* * *\end{array}$ & $\begin{array}{c}(0,54 \pm 0,004) \times 10^{2} \\
* * *\end{array}$ & $\begin{array}{c}(0,49 \pm 0,005) \times 10^{2} \\
* * *\end{array}$ & $(0,65 \pm 0,002) \times 10^{2}$ \\
\hline & 3 & $\begin{array}{c}(0,61 \pm 0,004) \times 10^{2} \\
* * *\end{array}$ & $\begin{array}{c}(0,56 \pm 0,004) \times 10^{2} \\
* * *\end{array}$ & $\begin{array}{c}(0,51 \pm 0,005) \times 10^{2} \\
* * *\end{array}$ & $(0,67 \pm 0,004) \times 10^{2}$ \\
\hline & 4 & $\begin{array}{c}(0,62 \pm 0,004) \times 10^{2} \\
* * *\end{array}$ & $\begin{array}{c}(0,58 \pm 0,003) \times 10^{2} \\
* * *\end{array}$ & $\begin{array}{c}(0,53 \pm 0,004) \times 10^{2} \\
* * *\end{array}$ & $(0,70 \pm 0,005) \times 10^{2}$ \\
\hline $\begin{array}{l}\text { S. aureus, } \\
\text { в } 25 \text { г }\end{array}$ & $1-4$ & \multicolumn{4}{|c|}{ Не виявлено } \\
\hline $\begin{array}{l}\text { L. mono- } \\
\text { cytogenes, } \\
\text { в } 25 \text { г }\end{array}$ & $1-4$ & \multicolumn{4}{|c|}{ Не виявлено } \\
\hline $\begin{array}{l}\text { Salmonella, } \\
\quad \text { в } 25 \Gamma\end{array}$ & $1-4$ & \multicolumn{4}{|c|}{ Не виявлено } \\
\hline
\end{tabular}

Найбільший середній показник КУО бактерій роду Proteus виявлено в печінці курчатбройлерів контрольної групи $\left((1,02 \pm 0,07) \times 10^{2}\right.$ КУО), а найменший - у печінці курчатбройлерів 3-ї дослідної групи. Встановлено, що достовірно $(\mathrm{p} \leq 0,05)$ нижчий середній показник КУО бактерій роду Proteus серед проб усіх дослідних груп реєструється лише в 3-й дослідній групі $\left((0,72 \pm 0,04) \times 10^{2}\right.$ КУО) у порівнянні з контрольними пробами.
Середній показник КУО МАФАнМ усіх дослідних проб м'язової частини шлунку достовірно менший у порівнянні з контрольними пробами. Найбільше значення КУО МАФАнМ реєструється у пробах контрольної групи $(9,26 \pm 0,17) \times 10^{3}$ КУО, а найменше - у пробах 3-ї дослідної групи $(8,11 \pm 0,08) \times 10^{3}$ КУО.

Середній показник КУО БГКП м'язової частини шлунку достовірно нижчий у 2-й $\left((7,04 \pm 0,08) \times 10^{2}\right.$ КУО) та 3 -й $\left((6,87 \pm 0,09) \times 10^{2}\right.$ 


\section{ВЕТЕРИНАРНА МЕДИЦИНА}

КУО) дослідних групах, порівнюючи 3 контрольними пробами $\left((7,51 \pm 0,16) \times 10^{2}\right.$ КУО). Найбільше значення КУО БГКП виявлено в контрольній групі, а найменше - у 3-й дослідній.

Середній показник бактерії роду Proteus м'язової частини шлунку достовірно нижчий $(\mathrm{p} \leq 0,05)$ у 2 -й $(0,98 \pm 0,01) \times 102 \quad$ КУО $)$ та 3 -й $((0,92 \pm 0,02) \times 102$ КУО) дослідних групах, порівнюючи 3 контрольною $(1,15 \pm 0,06) \times 102$ КУО). Найбільше значення спостерігається в контрольних пробах, а найменше - у пробах 3-ї дослідної групи.

Із проведених досліджень загальної бактеріальної контамінації продуктів забою курчатбройлерів у разі збагачення раціону НМКД «Мікростимулін» встановлено, що показники умовнопатогенних мікроорганізмів (МАФАнМ, БГКП і бактерії роду Proteus) не перевищують допустимих рівнів [14] як у скелетних м'язах, так і у серці, печінці та м'язовій частині шлунку.

Дослідження білих та червоних м'язів показало, що середні значення бактеріальної контамінації всіх дослідних груп достовірно нижчі за середні значення контрольної групи протягом усього періоду дослідження за температури $0-4{ }^{\circ} \mathrm{C}$.

Проведеними дослідженнями з визначення загальної бактеріальної контамінації серця, печінки та м'язової частини шлунку курчат-бройлерів усіх дослідних і контрольної груп встановлено, що найбільші значення реєструвалися у зразках контрольної групи, а найменші - у 3-й дослідній групі, курчатам-бройлерам якої випоювали НМКД «Мікростимулін» у найбільшій дозі - 20 мл/л води. Дослідженнями підтверджено, що 3 підвищенням дози НМКД «Мікростимулін» загальна бактеріальна контамінація продуктів забою курчат-бройлерів знижується. Очевидно це пов'язано 3 дією на мікроорганізми складників НМКД «Мікростимулін», зокрема таких наномікроелементів, як срібло, мідь і цинк, які володіють вираженими бактерицидними властивостями [17], а для германію характерна виражена антиоксидантна дія. Магній також володіє мікробоцидною активністю, будучи наногенератором наноенергії i, очевидно, коливальних рухів, що веде до розпаду поверхні молекул бактеріальної стінки, зміни функції плазмід, порушення адгезивної здатності мікроорганізмів, а отже, сприяє загибелі бактеріальних клітин [1]. Бактерії роду S. aureus, L. monocytogenes i Salmonella не були виявлені в зразках продуктів забою протягом усього досліджуваного періоду.

\section{Висновки:}

1. Найменші значення умовно-патогенної мікрофлори МАФАнМ, БГКП і бактерії роду Proteus як у скелетних м'язах, так і в серці, печінці і м'язовій частині шлунку, встановлено у 3-й дослідній групі, курчатам-бройлерам якої випоювали НМКД «Мікростимулін» у дозі 20 мл/дм ${ }^{3}$ води.

2. Застосування НМКД «Мікростимулін» негативно впливає на розвиток умовно-патогенних мікроорганізмів як за життя курчат-бройлерів, так і за умов зберігання продуктів забою за температури $0-4^{\circ} \mathrm{C}$ в холодильній камері.

3. Найбільші значення умовно-патогенних мікроорганізмів реєструються в продуктах забою курчат-бройлерів контрольної групи, проте максимально допустимі рівні не перевищували як у м'язах, так і у досліджуваних субпродуктах.

4. Бактерій роду $S$. aureus, L. monocytogenes i Salmonella у м'язах та досліджуваних субпродуктах як у контрольній, так і в дослідній групі не виявлено протягом визначеного терміну дослідження у випадку зберігання ї у холодильній камері за температури $0-4{ }^{\circ} \mathrm{C}$.

5. Продукти забою курчат-бройлерів у разі збагачення раціону НМКД «Мікростимулін» за життя контамінуються бактеріями гірше протягом усього встановленого терміну зберігання та температури $0-4{ }^{\circ} \mathrm{C}$, тому вони можуть випускатися для реалізації без обмежень.

Перспективи подальших досліджень полягають у проведенні фізико-хімічних досліджень продуктів забою, оцінці показників їх безпечності та якості після застосування НМКД «Мікростимулін» курчатам-бройлерам. 


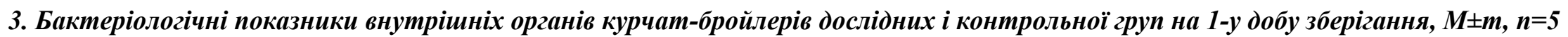

\begin{tabular}{|c|c|c|c|c|c|c|c|}
\hline \multirow{2}{*}{$\begin{array}{c}\text { Групи/дози } \\
\text { НМКД }\end{array}$} & \multirow[b]{2}{*}{$\begin{array}{c}\text { Досліджуваний } \\
\text { орган }\end{array}$} & \multicolumn{6}{|c|}{ Показники } \\
\hline & & $\begin{array}{c}\text { МАФАнМ, КУО } \\
\text { в } 1 \text { г } \\
\end{array}$ & БГКП в 1 г & $\begin{array}{l}\text { Salmonella, } \\
\text { в } 25 \text { г }\end{array}$ & $\begin{array}{l}\text { S. aureus, } \\
\text { в } 25 \text { г } \\
\end{array}$ & $\begin{array}{c}\text { L.monocytogenes, } \\
\text { в } 25 \text { г } \\
\end{array}$ & $\begin{array}{c}\text { Proteus, } \\
\text { в } 25 \text { г }\end{array}$ \\
\hline $\begin{array}{c}1 \\
\left(1 \text { мл/дм }{ }^{3}\right)\end{array}$ & \multirow{4}{*}{ Серце } & $\begin{array}{c}(7,72 \pm 0,14) \times 10^{3} \\
*\end{array}$ & $(4,94 \pm 0,12) \times 10^{2}$ & Не виявлено & Не виявлено & Не виявлено & $(0,92 \pm 0,04) \times 10^{2}$ \\
\hline $\begin{array}{c}2 \\
\left(10 \text { мл/ дм }{ }^{3}\right)\end{array}$ & & $\begin{array}{c}(7,34 \pm 0,15) \times 10^{3} \\
* * *\end{array}$ & $\begin{array}{c}(4,56 \pm 0,13) \times 10^{2} \\
* *\end{array}$ & Не виявлено & Не виявлено & Не виявлено & $(0,86 \pm 0,03) \times 10^{2}$ \\
\hline $\begin{array}{c}3 \\
\left(20 \text { мл/ дм }{ }^{3}\right)\end{array}$ & & $\begin{array}{c}(7,16 \pm 0,13) \times 10^{3} \\
* * *\end{array}$ & $\begin{array}{c}(4,33 \pm 0,12) \times 102 \\
* * *\end{array}$ & Не виявлено & Не виявлено & Не виявлено & $\begin{array}{c}(0,80 \pm 0,03) \times 102 \\
*\end{array}$ \\
\hline Контрольна & & $(8,51 \pm 0,20) \times 10^{3}$ & $(5,21 \pm 0,12) \times 10^{2}$ & Не виявлено & Не виявлено & Не виявлено & $(1,02 \pm 0,07) \times 10^{2}$ \\
\hline $\begin{array}{c}1 \\
\left(1 \text { мл/ дм }{ }^{3}\right)\end{array}$ & \multirow{4}{*}{ Печінка } & $\begin{array}{c}(7,43 \pm 0,09) \times 10^{3} \\
* *\end{array}$ & $\begin{array}{c}(5,76 \pm 0,05) \times 102 \\
* *\end{array}$ & Не виявлено & Не виявлено & Не виявлено & $(0,88 \pm 0,06) \times 10^{2}$ \\
\hline $\begin{array}{c}2 \\
\left(10 \text { мл/ дм }{ }^{3}\right)\end{array}$ & & $\begin{array}{c}(7,19 \pm 0,10) \times 10^{3} \\
* * *\end{array}$ & $\begin{array}{c}(5,32 \pm 0,07) \times 102 \\
* * *\end{array}$ & Не виявлено & Не виявлено & Не виявлено & $(0,78 \pm 0,08) \times 10^{2}$ \\
\hline $\begin{array}{c}3 \\
\left(20 \text { мл/ дм }{ }^{3}\right)\end{array}$ & & $\begin{array}{c}(7,01 \pm 0,05) \times 10^{3} \\
* * *\end{array}$ & $\begin{array}{c}(4,90 \pm 0,13) \times 102 \\
* * *\end{array}$ & Не виявлено & Не виявлено & Не виявлено & $\begin{array}{c}(0,72 \pm 0,04) \times 102 \\
*\end{array}$ \\
\hline Контрольна & & $(8,41 \pm 0,11) \times 10^{3}$ & $(6,28 \pm 0,11) \times 10^{2}$ & Не виявлено & Не виявлено & Не виявлено & $(0,97 \pm 0,07) \times 10^{2}$ \\
\hline $\begin{array}{c}1 \\
\left(1 \text { мл/ дм }{ }^{3}\right)\end{array}$ & \multirow{4}{*}{$\begin{array}{c}\text { M'язова частина } \\
\text { шлунку }\end{array}$} & $(8,62 \pm 0,15) \times 10^{3}$ & $(7,21 \pm 0,10) \times 10^{2}$ & Не виявлено & Не виявлено & Не виявлено & $(1,04 \pm 0,03) \times 10^{2}$ \\
\hline $\begin{array}{c}2 \\
\left(10 \text { мл/ дм }{ }^{3}\right)\end{array}$ & & $\begin{array}{c}(8,52 \pm 0,15) \times 10^{3} \\
*\end{array}$ & $\begin{array}{c}(7,04 \pm 0,08) \times 102 \\
*\end{array}$ & Не виявлено & Не виявлено & Не виявлено & $\begin{array}{c}(0,98 \pm 0,01) \times 102 \\
*\end{array}$ \\
\hline $\begin{array}{c}3 \\
\left(20 \text { мл/ дм }{ }^{3}\right)\end{array}$ & & $\begin{array}{c}(8,11 \pm 0,08) \times 10^{3} \\
* * *\end{array}$ & $\begin{array}{c}(6,87 \pm 0,09) \times 102 \\
* *\end{array}$ & Не виявлено & Не виявлено & Не виявлено & $\begin{array}{c}(0,92 \pm 0,02) \times 102 \\
* *\end{array}$ \\
\hline Контрольна & & $(9,26 \pm 0,17) \times 10^{3}$ & $(7,51 \pm 0,16) \times 10^{2}$ & Не виявлено & Не виявлено & Не виявлено & $(1,15 \pm 0,06) \times 10^{2}$ \\
\hline
\end{tabular}




\section{БІБЛІОГРАФІЯ}

1. Наноматериалы и нанотехнологии в ветеринарной практике / [Борисевич Б. В., Каплуненко В. Г., Косинов Н. В. и др.]. - К. : ВД «Авицена», 2012. $-512 \mathrm{c}$.

2. Бублик М. Аналіз виробництва м'яса птиці в Україні / М. Бублик // Економічний аналіз. 2011. - Вип. 9, Ч. 1. - С. 44-47.

3. Добавка мікроелементна кормова «Мікростимулін». Технічні умови. ТУ У 15.7-35291116009:2011.

4. Патент на корисну модель, МПК (2006) В01J 13/00, В82B 3/00. Спосіб отримання аквахелатів нанометалів «Ерозійно-вибухова нанотехнологія отримання аквахелатів нанометалів» / Косінов М. В., Каплуненко В. Г. - № 29856 Україна ; опубл. 25.01.2008, Бюл. № 2/2008. - 4 с.

5. Застосування наномікроелементної кормової суміші у птахівництві : методичні рекомендації / [Коцюмбас I., Величко В., Каплуненко В., Авдос'єва І. та ін.]. - К., 2014. - 15 с.

6. Лопатин Л. В. Стан і перспективи розвитку птахівництва в Україні / Л. В. Лопатин // Аграрний вісник Причорномор'я. - 2012. - Вип. 65. C. 42-46.

7. Мікробіологія харчових продуктів і кормів для тварин. Горизонтальний метод виявлення та підрахування Listeria monocytogenes (ISO 112902 : 2003, IDT) : ДСТУ ISO 11290-2 : 2003.[Чинний від 2003.01.01]. - К. : Державний комітет України з питань технічного регулювання та споживчої політики, 2003. - (Національний стандарт України).

8. Мясо птицы. Субпродукты и полуфабрикаты птичьи. Методы отбора и подготовка проб к микробиологическим исследованиям : ГОСТ 7702.2.0-95. - [Действителен от 1997.01.01]. Т.4. - Л., 2000. -284 c.

9. Мясо птицы, субпродукты и полуфабрикаты птичьи. Методы определения количества мезофильных аэробных и факультативно-анаэробных микроорганизмов. Мясная продукция и яйцепродукты : ГОСТ 7702.2.1-95. - Т.4. - Л., 2000. $284 \mathrm{c}$.

10. Мясо птицы, субпродукты и полуфабрикаты птичьи. Методы выявления и определения количества бактерий группы кишечных палочек (колиформных бактерий родов Escherichia, Citrobacter, Enterobacter, Klebsiella, Serratia).
Мясная продукция и яйцепродукты : ГОСТ 7702.2.2.-95. - Т.4. - Л., 2000. - 284 с.

11. Мясо птицы, субпродукты и полуфабрикаты птичьи. Методы выявления бактерий рода Proteus. Мясная продукция и яйцепродукты : ГОСТ 7702.2.7-95. - Т.4. - Л., 2000. - 284 с.

12. Мясо птицы, субпродукты и полуфабрикаты птичьи. Методы выявления сальмонелл. Мясная продукция и яйцепродукты : ГОСТ 7702.2.3-93. - Т.4. - Л., 2000. - 284 с.

13. Мясо птицы, субпродукты и полуфабрикаты птичьи. Методы выявления и определения количества Stafhylococcus aureus (ГОСТ 7702.2.4-93) : ГОСТ 7702.2.4-95. - [Действителен от 1997.01.01]. - Т.4. - Л., 2000. - 284 с.

14. Обов'язковий мінімальний перелік досліджень сировини, продукції тваринного та рослинного походження, комбікормової сировини, комбікормів, вітамінних препаратів та ін., які слід проводити в державних лабораторіях ветеринарної медицини i, за результатами яких видається ветеринарне свідоцтво (ф-2), затверджений Наказом Державного департаменту ветеринарної медицини України від 03.11.1998 № 16 та зареєстрований в Міністерстві юстиції України 30.11 .98 за № 761/3201 зі змінами, затвердженими наказом Державного департаменту ветеринарної медицини від 27.09.2004 №107 і зареєстрованими в Міністерстві юстиції України 04.10.2004 за № $1249 / 9848$.

15. Фотіна $Г$. А. Фармако-токсикологічна та клінічна оцінка хіміко-терапевтичних засобів для схеми ротації в птахівництві : автореф. дис. на здобуття наук. ступеня д. вет. н. / Г. А. Фотіна. - Львів, 2015. $-41 \mathrm{c.}$

16. Фотіна $\Gamma$. A. Визначення лікувальнопрофілактичної ефективності нового препарату «Мікростимулін» за експериментального ешерихіозу курчат / Г. А. Фотіна, А. В. Коваленко // Вісник Житомирського нац. агроекологічного університету. Серія : Вет. медицина. - 2012. Вип. 2 (31). - Т. 1. - С. 151-156.

17. Adekalu J. B. Stimulation of element absorbtion by major in vitro / J. B. Adtkalu, F. W. Heaton // Proc. Nutr. Soc. - 1992. - V. 51, №1. P. 61-65. 